\title{
Cortical Lewy body dementia: clinical features and classification
}

\author{
W R G GIBB, * P J LUTHERT, $\dagger$ I JANOTA, $\uparrow$ P L LANTOS $\dagger$ \\ From the Departments of Neuropathology, National Hospitals for Nervous Diseases, Maida Vale, ${ }^{*}$ and Institute \\ of Psychiatry, $\dagger$ London, UK
}

SUMMARY Seven patients, aged 65-72 years, are described with dementia and cortical Lewy bodies. In one patient a Parkinsonian syndrome was followed by dementia and motor neuron disease. In the remaining six patients dementia was accompanied by dysphasia, dyspraxia and agnosia. One developed a Parkinsonian syndrome before the dementia, in three cases a Parkinsonian syndrome occurred later, and in two cases not at all. All patients showed Lewy bodies and cell loss in the substantia nigra, locus coeruleus and dorsal vagal nucleus, as in Parkinson's disease. The severity of cell loss in the nucleus basalis varied from mild to severe. Lewy bodies were also present in the parahippocampus and cerebral cortex, but Alzheimer-type pathology was mild or absent, and insufficient for a diagnosis of Alzheimer's disease. Patients with moderate or severe dementia, some with temporal or parietal features, may have cortical Lewy body disease, Alzheimer's disease, or a combination of the two. Cortical Lewy body disease may be associated with dementia in Parkinson's disease more often than realised, but is not necessarily associated with extensive Alzheimer pathology.

Some patients with dementia, with aphasia, agnosia and apraxia do not have Alzheimer's disease or Pick's disease. $^{1-5}$ This is also true for some patients with visuo-spatial and language deficits accompanied by a Parkinsonian syndrome. ${ }^{6}$ A number of reports indicate that dementia with or without Parkinsonian features may be associated with Lewy bodies in the cerebral cortex, often in association with neurofibrillary tangles and senile plaques. ${ }^{78}$ It has been suggested that the quantity of Alzheimer pathology, cortical Lewy body disease and severity of dementia are correlated, implying that Alzheimer's disease rather than cortical Lewy body disease, is the most likely cause of the dementia. ${ }^{10}$ However, dementia with Lewy bodies in the cerebral cortex can occur in the absence of tangles and plaques, and in the presence of Parkinson's disease ${ }^{11}{ }^{12}$ and Hallervorden-Spatz disease. ${ }^{13-16}$ Lewy bodies in the cerebral cortex may be associated with dementia more frequently than recognised, and may help to explain dementia with temporal and parietal features.

Address for reprint requests: Dr W R G Gibb, Department of Neurology, Guys Hospital, London SE1 9RT, UK.

Received 7 June 1988 and in revised form 24 September 1988. Accepted 27 September 1988
We now report seven patients, representing a different series from that previously reported, ${ }^{8}$ who presented with memory failure, six of whom showed aphasia, apraxia or agnosia. Five also had a Parkinsonian syndrome. Various parts of the cerebral cortex contained Lewy bodies, but numbers of tangles and plaques were inadequate for the diagnosis of Alzheimer's disease.

\section{Patients and methods}

The seven cases examined were collected in one neuropathology laboratory. Six came from a group of approximately 110 brains of patients referred with dementia and a group of 30 referred with Parkinsonian disorders between 1980 and 1984. The brains were fixed in $10 \%$ formol-saline. Blocks were taken from the cerebral hemispheres (frontal, central, parietal, temporal and occipital regions), from the hippocampus, nucleus basalis of Meynert, hypothalamus, thalamus, striatum, midbrain, pons, medulla and cerebellum. Sections of $7 \mu \mathrm{m}$ and $14 \mu \mathrm{m}$ thickness were stained with haematoxylin and eosin (H and E), Nissl's cresyl violet, luxol-fast bluecresyl violet, Holzer's stain, and impregnated with silver according to Bielschowsky, or Glees and Marsland.

In the cerebral cortex the number of Lewy bodies was counted directly at $\times 312$ magnification, in single $7 \mu \mathrm{m}$-thick $\mathrm{H}$ and $\mathrm{E}$-stained sections, by choosing a site at random and making five adjacent sweeps (each $0 \cdot 38 \mathrm{~mm}$ wide) perpen- 
Table 1 Summary of clinical characteristics

\begin{tabular}{|c|c|c|c|c|}
\hline $\begin{array}{l}\text { Pt } \\
\operatorname{sex}\end{array}$ & $\begin{array}{l}\text { Onset age } \\
\text { years }\end{array}$ & $\begin{array}{l}\text { Duration } \\
\text { years }\end{array}$ & First symptom/sign & Later symptoms/signs \\
\hline 1.M & 70 & $1 \cdot 5$ & $\begin{array}{l}\text { Failure of recent and } \\
\text { remote memory }\end{array}$ & $\begin{array}{l}\text { Spatial disorientation, dyspraxia, dysphasia, no Parkinsonian } \\
\text { syndrome }\end{array}$ \\
\hline 2.M & 68 & $2 \cdot 5$ & Parkinsonian syndrome & $\begin{array}{l}\text { Memory failure, spatial disorientation, prosopagnosia, dysphasia, } \\
\text { colour agnosia, dyslexia }\end{array}$ \\
\hline $\begin{array}{l}\text { 3.M } \\
\text { 4.M } \\
\text { 5.M } \\
\text { 6.M } \\
\text { 7.F }\end{array}$ & $\begin{array}{l}65 \\
72 \\
69 \\
71 \\
66\end{array}$ & $\begin{array}{l}7 \\
7 \\
3 \cdot 5 \\
6 \\
0 \cdot 5\end{array}$ & $\begin{array}{l}\text { Short-term memory failure } \\
\text { Parkinsonian syndrome } \\
\text { Memory failure } \\
\text { Memory failure } \\
\text { Memory failure }\end{array}$ & $\begin{array}{l}\text { Dyspraxia, dysphasia, Parkinsonian syndrome } \\
\text { Motor neuron disease, dementia } \\
\text { Dyspraxia, dysphasia, spatial disorientation, muscular rigidity } \\
\text { Dysphasia, Parkinsonian syndrome } \\
\text { Prosopagnosia, spatial disorientation, no Parkinsonian syndrome }\end{array}$ \\
\hline
\end{tabular}

dicular to the cortical surface from pia to white matter. The Lewy body was defined as an eosinophilic cytoplasmic inclusion with a halo. Pale bodies which fail to stain with eosin were not counted. Cortical sections of $14 \mu \mathrm{m}$-thickness impregnated with silver according to Glees and Marsland were used to count plaques and tangles in the same way. Counts of Lewy bodies, plaques and tangles in the cortex were expressed as the number per $\mathrm{mm}^{2}$ of cortical crosssectional area.

In the substantia nigra counts of pigmented cells and cells with Lewy bodies were made in one or two unilateral $7 \mu \mathrm{m}$ thick sections.

\section{Case histories (summarised in table 1)}

Case 1. A man aged 72 years at death worked as an industrial chemist until he retired at the age of 64 years. When he was aged 70 years his wife noted that his memory for recent events was poor. He failed to learn new information and had difficulty recalling names of longstanding acquaintances. He tended to forget his wife's name and had difficulty finding his way around the house. Within 18 months he was unable to shave and dress without help. Some weeks before presentation his wife noted that nocturnal myoclonic limb jerks greatly increased in frequency.

On examination he was disorientated and he had marked dyspraxia and nominal dysphasia. He named a telephone "a cabinet", and he called a magnifying glass "a barometer". He was unable to name other common objects, and could not recall his address in full. He was thought to be moderately demented. An EEG showed marked bilateral abnormalities with the dominant activity at $6 \mathrm{~Hz}$ and diffuse slow frequencies down to $2 \mathrm{~Hz}$. A technetium 99 brain scan was normal, but a lumbar air encephalogram showed considerable enlargement of the ventricular system and pooling of air over the cortex. The degree of ventricular dilatation suggested hydrocephalus so a ventriculo-peritoneal shunt was inserted. His immediate post-operative recovery was satisfactory, but he died a month later from a pulmonary embolus.

Case 2. A 70 year old retired accountant had a radical total gastrectomy at the age of 55 years for an anaplastic gastric carcinoma. At the age of 63 years his blood film was macrocytic and serum and red cell folate levels were in the borderline range, with normal vitamin B 12 levels. Thereafter he was given regular folate and vitamin B12 replacement and these levels remained above the normal range. At the age of 65 he retired, but often became muddled and believed he was still working. At the age of 68 years he developed rest tremor of the right hand with muscular rigidity of the limbs. He was prescribed levodopa with a decarboxylase inhibitor (Sinemet). In the next 3 months he had difficulties with word finding and with recognising familiar faces. He developed spatial disorientation and impairment of short-term memory. At times he had visual hallucinations and urinary incontinence. Neuropsychological assessment showed his WAIS verbal IQ was 98, performance IQ 72, and full scale IQ 86. The low performance IQ and difficulty with the Face Hands test suggested parietal lobe damage. A low score in the Verbal Learning Test suggested verbal memory impairment. He was only partially orientated in time and place and showed perserveration of ideas. There was colour agnosia, dysphasia and dyslexia. His downgaze was poor, but horizontal gaze was normal.

One year from the onset he was moderately demented an $\$$ he was unable to recall his previous occupation or his age. $\mathrm{H}$ was uncooperative, of labile mood, and had restless night $\Omega \rightarrow$ He was admitted to a long-stay hospital where he remaine $T$ until his death 2.5 years from the onset.

Case 3. ${ }^{17}$ This 72 year old man, an introverted and anxiof person, worked as a school teacher until he retired at the age of 60 years. At the age of 56 years he developed bouts irritability and depression, with mild memory failure. At the age of 65 years he had difficulty recalling previous conversations and tended to get lost. A year later his gait was slow and he often stumbled. He required help with dressing, became unkempt and forgetful. At 68 years he had poor short-term memory, poor concentration, mild dysphasia, dressing dyspraxia and constructional apraxia. He was orientated in month and year, but not for the day of the week and the date. He retained two out of three items at 30 seconds and one out of three at 60 seconds, was unable to do serial sevens, but could do serial threes rapidly. CT showed ventricular enlargement and prominent sulci.

By the age of 70 years he had visual and auditory hallucinations, global cognitive impairment, and was unable to care for himself. He showed naming difficulties for common objects, calling a pen "a cylinder". He showed paragrammatical speech with neologisms, disorientation in time and place and difficulties with both recent and remote memory. He was unable to copy simple drawings or a simple sentence. His WAIS vocabulary score was 50 and he performed poorly on tests of memory, language and parietal lobe function, confirming the diagnosis of dementia. An EEG $\frac{7}{0}$ showed a slow but symmetrical rhythm, at or below $8 \mathrm{~Hz}$, frequent independent slow waves and occasional isolated $\mathrm{N}$ bitemporal sharp waves. CT at 70 and 71 years suggested further enlargement of the lateral ventricles. His vocabulary 
score fell to 39 by the age of 71 years. At the age of 72 years he had a shuffling gait, rest tremor and bradykinesia, but no muscular rigidity. Six months later he had several generalised convulsions and died 2 weeks later from bronchopneumonia. Case 4. This 79 year old man was first examined after a fall at the age of 72 years. His responses to questions were delayed, but he was not thought to be significantly demented. He had a mask-like face, muscular rigidity of limbs, and a shuffling gait, which improved with levodopa. One year later he developed wasting and fasciculation of small hand muscles. Two years later higher doses of levodopa produced a further dramatic improvement in mobility. By the age of 78 years he was unaware of his disability, his memory was poor, and he was believed to be demented. He had lost weight and developed considerable proximal muscle wasting. There was minimal muscular rigidity in the arms, but tone in the legs was normal. There was wasting of muscles of the shoulders, thighs, hands and calves with fasciculations, absent tendon reflexes and extensor plantar responses. His gait was slow and shuffling. An EMG showed fasciculations in arms and legs with normal nerve conduction studies. The patient died 7 years later after a femoral fracture.

Case 5. This 72 year old man developed poor recent memory at the age of 69 years, and three years later showed dressing apraxia and spatial disorientation. He was unable to find his way around his home and often believed it was not his own. His recent memory was poor, he was unable to manipulate matches which he called "drawing pins", and he was unable to put on a pullover. He was apathetic and incontinent of urine, but at times he was agitated and given a few doses of haloperidol ( $1.5 \mathrm{mg})$. Three months later he was severely demented, unable to recognise his wife and unable to communicate. All his limbs were described as "very rigid". There were bilateral grasp and pout reflexes. He died 3.5 years after the onset of memory impairment.

Case 6. This 77 year old Polish man was assaulted at the age of 70 years and two ribs were fractured. A year later he became increasingly forgetful and tended to wander. Five years later he spoke only in Polish having once been fluent in English. He showed moderately severe dementia, but there was no muscular rigidity or bradykinesia. CT showed moderate diffuse cortical shrinkage and ventricular dilatation. A single dose of flupenthixol (20 mg intramuscularly) was given for nocturnal confusion, followed by haloperidol ( $0.5 \mathrm{mg}$ daily). His dementia progressed and he developed a Parkinsonian syndrome complicated by venous and pressure ulcerations of the legs and flexion contractures of the knees. He died of bronchopneumonia 6 years from the onset.

Case 7. This 66 year old woman consumed 12 pints of beer daily in the year before she presented. At the age of 66 years she developed memory impairment with hallucinations and urinary incontinence over a period of 5 months. She failed to recognise faces, was disorientated and tended to wander. Thioridazine ( $50 \mathrm{mg}$ daily) was prescribed. A random blood glucose was $23.5 \mathrm{mmol} / \mathrm{l}$, but tests of liver function were normal. An EEG was diffusely abnormal with low voltage theta waves and occasional slow activity occurring bilaterally. CT showed mildly dilated cortical sulci. Glibenclamide, metformin, and chlorpromazine $(100 \mathrm{mg}$ as required) were prescribed. In the next month her dementia progressed rapidly so that she became restless, failed to recognise her family, language became incoherent and she developed auditory hallucinations and incontinence of urine. She died 6 months from the onset.

\section{Results}

Pathological findings. Brain weights were not generally reduced (table 2 ). In Cases 1 and 2 cortical sulci were moderately widened, especially frontally, and temporal and frontal horns of the lateral ventricles were mildly dilated. In Cases 3 and 5 the lateral ventricles were moderately enlarged. In Case 7 there was mild fronto-parietal atrophy with moderate dilatation of the temporal horns of the lateral ventricles. All the brainstems showed pallor of the substantia nigra and locus coeruleus.

Microscopic examination in all cases showed moderate or severe cell loss with Lewy bodies in the substantia nigra (table 3, fig, a), locus coeruleus and dorsal vagal nucleus. Neuronal loss in the nucleus basalis varied from inapparent (Cases 2 and 4) to severe (Case 6). Cortical Lewy bodies were frequent in Cases 1, 2, 5-7 (fig, b). They were most numerous deeper in the parahippocampal gyrus, insular cortex, frontal and temporal lobes, and less frequent in parietal and occipital cortex. Lewy bodies never occurred in the hippocampus and were rare in the subiculum in Cases 5-7. None of the cases showed a conspicuous loss of cortical nerve cells and there was little gliosis. Many deep cortical cells without Lewy bodies showed abnormalities ranging from ill-defined cytoplasmic swelling to large pale inclusions. These pale inclusions were similar to those seen in the substantia nigra in these cases and in Parkinson's disease (fig, c and d). Their cerebral distribution followed that of Lewy bodies.

In Cases 1-5 the cortical Alzheimer-type pathology was generally mild and insufficient for a diagnosis of Alzheimer's disease (table 2). In Cases 1 and 2 plaques were infrequent in the parahippocampus and elsewhere in the temporal lobe, and were sparse or absent in other areas. Tangles were not found. In Cases 3-5 plaques were infrequent, and the occasional tangle was confined to the hippocampus and temporal lobe. In Cases 6 and 7 there were more plaques, and infrequent tangles in temporal and frontal cortex. The maximum numerical plaque density of $4 / \mathrm{mm}^{2}$ falls short of published criteria for the diagnosis of Alzheimer's disease.$^{18}$ In all cases neuronal loss and gliosis were not prominent and thinning of subcortical white matter did not occur. Granulovacuolar degeneration was absent in Cases 2-4, but was found in $13 \%$ of hippocampal pyramidal neurons in Cases 1 and 5, in $22 \%$ in Case 6 , and $40 \%$ in Case 7 . Occasional Hirano bodies were present in the hippocampus in Cases 1, and 4-7. Subcortical Alzheimer pathology was restric- 
Table 2 Summary of pathology in the parahippocampus and cerebral cortex

\begin{tabular}{|c|c|c|c|c|c|c|c|c|}
\hline & & \multicolumn{7}{|c|}{ Patient } \\
\hline & & 1 & 2 & 3 & 4 & 5 & 6 & 7 \\
\hline $\begin{array}{l}\text { Brain weight } \mathbf{g} \\
\text { Parahippocampus }\end{array}$ & $\begin{array}{l}\text { LB } \\
\text { plaques } \\
\text { tangles }\end{array}$ & $\begin{array}{l}1270 \\
++ \\
0 \\
0\end{array}$ & $\begin{array}{l}1410 \\
++ \\
++ \\
0\end{array}$ & $\begin{array}{l}1438 \\
+ \\
0 \\
0\end{array}$ & $\begin{array}{l}1414 \\
+ \\
+ \\
0\end{array}$ & $\begin{array}{l}1305 \\
++ \\
0 \\
0\end{array}$ & $\begin{array}{l}1147 \\
+++ \\
+++ \\
++\end{array}$ & $\begin{array}{l}\text { na } \\
++ \\
++ \\
+\end{array}$ \\
\hline Frontal & $\begin{array}{l}\text { LB } \\
\text { plaques } \\
\text { tangles }\end{array}$ & $\begin{array}{l}+ \\
+ \\
0\end{array}$ & $\begin{array}{l}++ \\
++ \\
0\end{array}$ & $\begin{array}{l}0 \\
0 \\
0\end{array}$ & $\begin{array}{l}++ \\
0 \\
0\end{array}$ & $\begin{array}{l}+ \\
++ \\
0\end{array}$ & $\begin{array}{l}++ \\
++ \\
+\end{array}$ & $\begin{array}{l}++ \\
\text { na } \\
\text { na }\end{array}$ \\
\hline Temporal & $\begin{array}{l}\text { LB } \\
\text { plaques } \\
\text { tangles }\end{array}$ & $\begin{array}{l}++ \\
0 \\
0\end{array}$ & $\begin{array}{l}0 \\
0 \\
0\end{array}$ & $\begin{array}{l}\mathbf{0} \\
\mathbf{0} \\
\mathbf{0}\end{array}$ & $\begin{array}{l}+ \\
+ \\
+\end{array}$ & $\begin{array}{l}++ \\
+ \\
0\end{array}$ & $\begin{array}{l}++ \\
++ \\
0\end{array}$ & $\begin{array}{l}+ \\
0\end{array}$ \\
\hline Insular & $\begin{array}{l}\text { LB } \\
\text { plaques } \\
\text { tangles }\end{array}$ & $\begin{array}{l}++ \\
0 \\
0\end{array}$ & $\begin{array}{l}\text { na } \\
\text { na } \\
\text { na }\end{array}$ & $\begin{array}{l}+ \\
0 \\
0\end{array}$ & $\begin{array}{l}\text { na } \\
\text { na } \\
\text { na }\end{array}$ & $\begin{array}{l}++ \\
+ \\
0\end{array}$ & $\begin{array}{l}++ \\
++ \\
0\end{array}$ & $\begin{array}{l}\text { na } \\
\text { na } \\
\text { na }\end{array}$ \\
\hline Occipital (mid-convexity) & $\begin{array}{l}\text { LB } \\
\text { plaques } \\
\text { tangles }\end{array}$ & $\begin{array}{l}0 \\
++ \\
0\end{array}$ & $\begin{array}{l}0 \\
++ \\
0\end{array}$ & $\begin{array}{l}0 \\
0 \\
0\end{array}$ & $\begin{array}{l}0 \\
0 \\
0\end{array}$ & $\begin{array}{l}0 \\
+ \\
0\end{array}$ & $\begin{array}{l}0 \\
0\end{array}$ & $\begin{array}{l}+ \\
\text { na } \\
\text { na }\end{array}$ \\
\hline Occipital (calcarine) & $\begin{array}{l}\text { LB } \\
\text { plaques } \\
\text { tangles }\end{array}$ & $\begin{array}{l}0 \\
+ \\
0\end{array}$ & $\begin{array}{l}+ \\
0 \\
0\end{array}$ & $\begin{array}{l}0 \\
0 \\
0\end{array}$ & $\begin{array}{l}\mathbf{0} \\
0 \\
0\end{array}$ & $\begin{array}{l}0 \\
0 \\
0\end{array}$ & $\begin{array}{l}0 \\
0\end{array}++$ & $\begin{array}{l}0 \\
0 \\
0\end{array}$ \\
\hline
\end{tabular}

$0=$ absent in five successive sweeps $(0.38 \mathrm{~mm}$ wide) from pia to subcortical white matter. Zero does not mean that a feature was entirely absent, but the sampled areas were sufficiently large to ensure that significantly high densities were not missed. $t=$ mild, fewer than 0.3 per $\mathrm{mm}^{2}$ of section area.

$++=$ moderate, $0.3-3.0$ per $\mathrm{mm}^{2}$ of section area.

$+++=$ severe, $3 \cdot 0-4 \cdot 0$ per $\mathrm{mm}^{2}$ of section area.

LB = Lewy body.

na $=$ not available.

ted to the occasional tangle in the brainstem, basal forebrain or hypothalamus.

\section{Discussion}

Seven patients of mean age 68.7 years (range 65-72) developed dementia. Six of them showed aphasia, apraxia, agnosia or spatial disorientation, suggestive of temporo-parietal dysfunction. The mean disease duration from onset to death was 4 years (range $0.5-$ 7), which is shorter than the mean duration of 10-12 years in untreated Parkinson's disease before the levodopa era. ${ }^{19}$ Two cases (Cases 1 and 7), with short survival of 1.5 and 0.5 years respectively, had no evidence of a Parkinsonian syndrome, and three others (Cases 3, 5, 6) developed dementia before Parkinsonian features. Cases 2 and 3 showed a rest

Table 3 Summary of pathology in the substantia nigra

\begin{tabular}{lll}
\hline Case & $\begin{array}{l}\text { Count of } \\
\text { pigmented } \\
\text { cells }\end{array}$ & $\begin{array}{l}\text { Count of pigmented } \\
\text { cells with } \\
\text { Lewy bodies }\end{array}$ \\
\hline 1 & 302 & 16 \\
2 & 104 & 15 \\
3 & 299 & 19 \\
4 & 360 & 17 \\
5 & 535 & 44 \\
6 & 220 & 7 \\
7 & 291 & 7 \\
\hline
\end{tabular}

Mean nigral cell counts in 25 controls aged $60-79$ years was $856 \cdot 1$ [SE.21.4]. tremor and the other three Parkinsonian cases had a bradykinetic-rigid syndrome. In Case 4 levodopa improved mobility and in Case 2 provoked confusion; it was not given in the other cases.

The subcortical distribution of Lewy bodies and neuronal loss was comparable with that of Parkinson's disease. In all cases there were Lewy bodies and pale inclusions in the cerebral cortex, but without enough plaques and tangles for Alzheimer's disease. ${ }^{1820}$ Lewy bodies were located mostly in the parahippocampal gyrus, frontal, temporal and insular cortex. In Case 4 the motor neuron disease (MND) may have been coincidental. However, Delisle and Carpenter ${ }^{21}$ who compared proximal axonal swellings located in anterior horn neurons in MND and controls found that one of the 22 controls had Parkinson's disease with large and numerous axonal swellings, not dissimilar from MND. Sporadic MND has also been described with Lewy bodies in anterior horn cells. ${ }^{22} 23$ Hirano ${ }^{22}$ reported a 55 year old man with a clinical course of 11 years characterised by shuffling gait and muscle wasting. Widespread "neurofibrillary change", degeneration of cells of the substantia nigra and loss of anterior horn cells with intracytoplasmic inclusions, remarkably similar to Lewy bodies, were observed. The possibility arises, therefore, that rare cases of Parkinson's disease with anterior horn cell damage might be associated with Lewy body degeneration in anterior horn cells rather than representing a coincidental association between Parkinson's disease and 

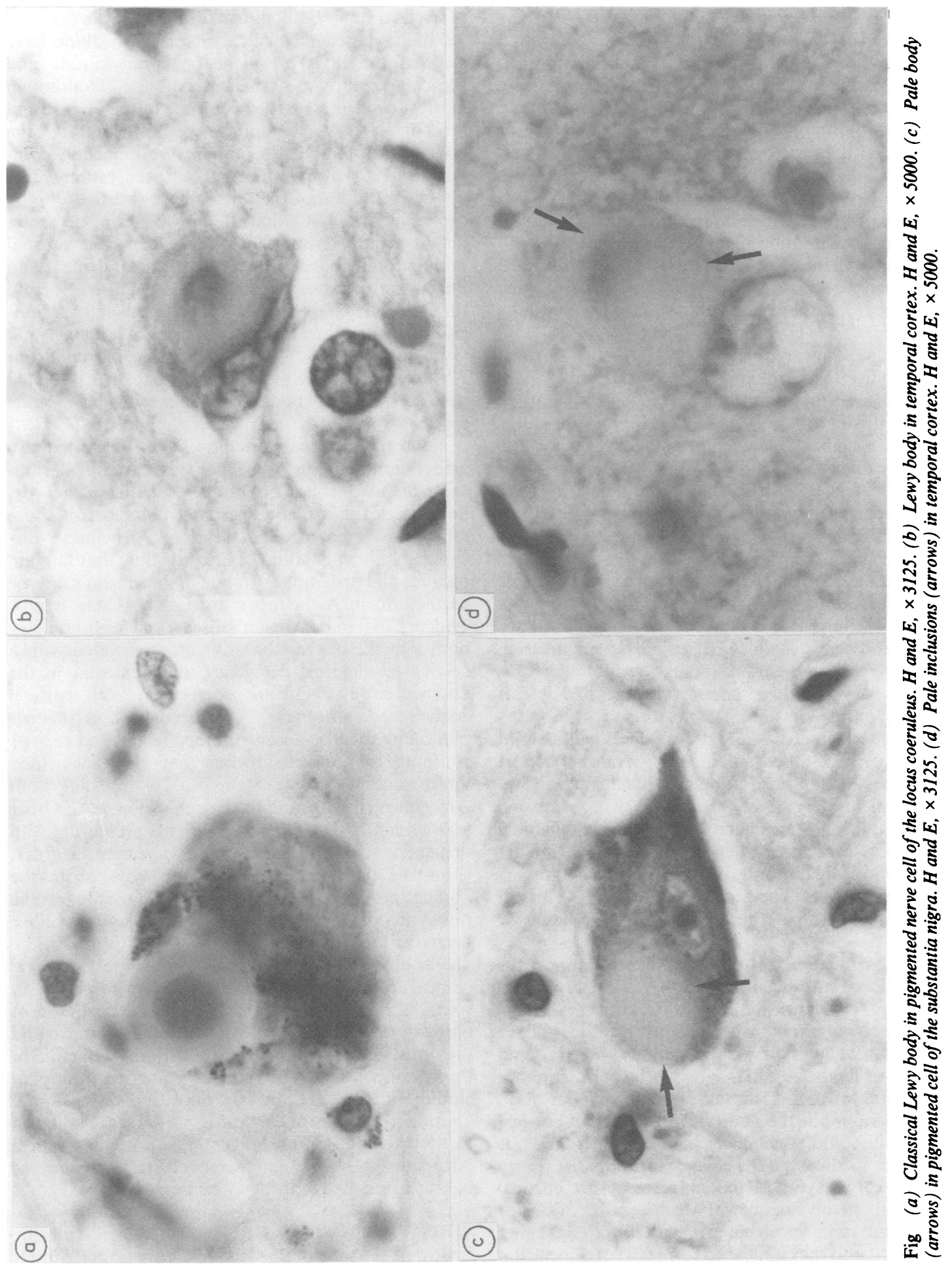
classical MND. One relevant patient described by Delisle $e t$ al developed MND at the age of 36, followed by extrapyramidal rigidity and dementia a few months before death at the age of 49 years. ${ }^{24}$ There were moderate numbers of cortical Lewy bodies, with mild Alzheimer pathology, and loss of anterior horn motor neurons with Lewy bodies in the spinal cord, but probably not in surviving motor neurons (slides reviewed by WRGG). Extension of Lewy bodies into anterior horn cells in Parkinson's disease has therefore not been shown. Indeed all recorded patients with MND accompanied by Lewy bodies in anterior horn cells have not been accompanied by Lewy bodies in the brainstem, ${ }^{22} 23$ so these disease entities may be mutually exclusive.

Many previous reports of patients with cortical Lewy bodies and dementia have come from Japan. Okazaki et al $^{7}$ first reported patients aged 68 and 70 years at death with dementia, Parkinsonian features and multiple cortical Lewy bodies. Although 21 other similar cases, aged 26-72 years, have been described, ${ }^{8-12}$ few characteristics of the dementia have been reported. One patient had topographical amnesia ${ }^{25}$ and another had bradyphrenia. ${ }^{26}$ In most cases a Parkinsonian syndrome developed with the dementia, but in four cases dementia was the sole clinical feature for the 3-10 year duration of the disease. ${ }^{27-30}$ The importance of neocortical neurofibrillary tangles and senile plaques has usually been stressed, but in seven cases these were sparse or absent. ${ }^{72}{ }^{12} 231-34$ Among seven recently described, two cases had dyscalculia, dyspraxia or topographical disorientation. ${ }^{3536}$ Cortical Alzheimer pathology was described as mild or absent in six out of 13 cases. ${ }^{35-37}$ Another report emphasises the temporo-parietal clinical features and the complete absence of Alzheimer changes in one case. ${ }^{8}$ Additional evidence supporting a possible association of cortical Lewy bodies and dementia comes from four reports of patients with Hallervorden-Spatz disease. These cases had multiple cortical Lewy bodies and pale inclusions, and no plaques or tangles. ${ }^{13-16}$

The classification of our cases depends upon the observation that the distribution of the brainstem pathology was identical to that in Parkinson's disease. Up to $30 \%$ of patients with Parkinson's disease have occasional Lewy bodies in the temporal lobe ${ }^{38-40}$ and some cases have a few Lewy bodies in both temporal and frontal lobes. ${ }^{91038}$ Indeed some such patients have had dementia, but the relative importance of cortical Lewy bodies and Alzheimer changes in these cases is not clear. In this study the cases of idiopathic Lewy body disease have had moderate or severe cortical Lewy body involvement (with the exception of Case 3 which had mild involvement) with little Alzheimer pathology, and they appear to form part of a spectrum of cortical Lewy body disease in Parkinson's disease.

Studies based on clinical observation alone have $\mathbb{D}$ stressed the high prevalence of bradykinesia and

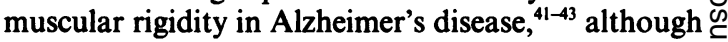
in most cases these signs occur late in the disease and $\overline{0}$ are of uncertain significance. In contrast the $D$ prevalence of moderate and severe dementia complicating Parkinson's disease has been estimated at about $20 \%,{ }^{44}$ although some believe this figure to be excessive ${ }^{45}$ implying that the prevalence of dementia may be about twice the $5-7 \%$ rate in the normal $\vec{F}$ population. Moderate or severe forms of dementia in Parkinson's disease seem to be indistinguishable from $\frac{C}{\sigma}$ that in Alzheimer's disease $e^{467}$ and are usually accom- $\frac{\overline{\bar{N}}}{\overline{0}}$ panied by deteriorating performance in language and $\vec{\nabla}$ visuo-spatial tasks. ${ }^{478}$ In the absence of significant 0 Alzheimer changes pathological changes associated ${ }^{\infty}$ with cortical Lewy bodies may be responsible in some $\overrightarrow{0}$ cases.

Neuropathological studies have suggested an $\vec{\omega}$ association between Alzheimer's disease and Parkinson's disease, ${ }^{49-51}$ but quantitive estimates of neocortical tangles and plaques usually fall short of those or established in controlled series of Alzheimer's dis- i ease. ${ }^{18} 1952$ Further studies failed to show that tangles, plaques and dementia correlate in Parkinson's disea of as they do in Alzheimer's disease. ${ }^{53-55}$ There is now evidence that in Parkinson's disease cell loss and Lew bodies in the nucleus basalis ${ }^{56}$ are associated with cortical cholinergic deficiency and dementia in the 음 absence of a significant correlation with cortical Alzheimer pathology.57-59 Nevertheless Alzheimer pathology may be a contributory factor and reporio $\vec{\omega}$ continue to appear showing that some demented $\mathbb{O}_{0}^{\circ}$ Parkinsonians have pathological features of both Alzheimer's disease and Parkinson's disease. ${ }^{6061}$ Other reports emphasise that some patients presenting with dementia, with or without a Parkinsonian disorder, show the pathology of Parkinson's disease in the $\frac{\mathrm{O}}{\mathrm{O}}$ absence of Alzheimer pathology. ${ }^{3662}$ In these cases the $\cong$ possibility of cortical Lewy body pathology may have $\overrightarrow{\vec{O}}$ been overlooked. ${ }^{46}$

Our observations of patients with temporo-parietal clinical features, dementia, cortical Lewy bodies and sparse tangles and plaques suggest that the presence of $\bar{\partial}$ cortical Lewy bodies may have an important and previously neglected association with the dementia of $\dot{0}$ Parkinson's disease. Future clinico-pathological studies of dementia in Parkinson's disease should $\delta$ consider the effects of cortical Lewy bodies in addition $₹$ to the two other important lesions; notably, cortical 윽 Alzheimer pathology, and nerve cell loss in the nucleus basalis associated with Lewy bodies.

WRGG was a Medical Research Council Training $\%$ Fellow at the time of this study. We are grateful to Dr $N$ 
L Hemsi, Dr J Kellett and Professor R Levy for permission to report clinical details of their patients. We also thank Dr M B Delisle for sending us slides of the spinal cord from one of their cases.

\section{References}

1 Woodard JS. Concentric hyaline inclusion body formation in mental disease. Analysis of twenty-seven cases. $J$ Neuropathol Exp Neurol 1962;21:442-9.

2 Tomlinson BE, Blessed G, Roth M. Observations on the brains of demented old people. J Neurol Sci 1970;11:205-42.

3 Sulkava R, Haltia M, Paetau A, Wikstrom J, Palo J. Accuracy of clinical diagnosis in primary degenerative dementia: correlation with neuropathological findings. J Neurol Neurosurg Psychiatry 1983;46:9-13.

4 Heilig CW, Knopman DS, Mastri AR, Frey W. Dementia without Alzheimer pathology. Neurology 1985;35:762-5.

5 Mölsä PK, Paljärvi L, Rinne JO, Rinne UK, Säkö E. Validity of clinical diagnosis in dementia: a prospective clinicopathological study. J Neurol Neurosurg Psychiatry 1985;48:1085-90.

6 Chui HC, Mortimer JA, Slager U, Zarow C, Bondareff W, Webster DD. Pathologic correlates of dementia in Parkinson's disease. Arch Neurol 1986;43:991-5.

7 Okazaki H, Lipkin LE, Aronson SM. Diffuse intracytoplasmic ganglionic inclusions (Lewy type) associated with progressive dementia and quadriparesis in flexion. $J$ Neuropathol Exp Neurol 1961;20:237-44.

8 Gibb WRG, Esiri MM, Lees AJ. Clinical and pathological features of diffuse cortical Lewy body disease (Lewy body dementia). Brain 1987;110:1131-53.

9 Yoshimura M. Corticale Veränderungen bei Paralysis agitans. Current Topics in Neuropathology 1982;7:77-91.

10 Yoshimura $M$. Cortical changes in the parkinsonian brain: a contribution to the delineation of "diffuse Lewy body disease". J Neurol 1983;229:17-32.

11 Ikeda K, Yoshimura T, Kato H. A case of idiopathic parkinsonism with many Lewy bodies in the cerebral cortex. Brain Nerve 1975;27:733-42.

12 Okeda R, Kayano T, Funata N, Kojima T, Miki M, Iwama H. An autopsy case of Parkinson's disease associated clinically with dementia terminating in akinetic mutism and pathologically with multiple Lewy bodies in the cerebral cortex. Brain Nerve 1982;38:761-7.

13 Helfand $M$. Status pigmentatus. Its pathology and its relation to Hallervorden-Spatz disease. J Nerv Ment Dis 1935;81:662-75.

14 Defendini R, Markesbery WR, Mastri AR, Duffy PE. Hallervorden-Spatz disease and infantile neuroaxonal dystrophy. J Neurol Sci 1973;20:7-23.

15 Dooling EC, Schoene WC, Richardson EP. Hallervorden-Spatz syndrome. Arch Neurol 1974;30:70-83.

16 Williamson K, Sima AAF, Curry B, Ludwin SK. Neuroaxonal dystrophy in young adults: a clinicopathological study of two unrelated cases. Ann Neurol 1982;11:335-43.

17 Philpot M, Colgan J, Janota I, Levy R. Dementia without Alzheimer pathology. Neurology 1986;36:133.

18 Tomlinson BE, Blessed G, Roth M. Observations on the brains of demented old people. J Neurol Sci 1970;11:205-42.

19 Wilcock GK, Esiri MM. Plaques, tangles and dementia: A quantitative study. $J$ Neurol Sci 1982;56:343-56.

20 Marttila RJ, Rinne UK. Epidemiology of Parkinson's disease. In: Poeck K, Freund H-J, Ganshirt H, eds. Proceedings of XIIIth World Congress of Neurology, Hamburg, 1985. Heidelberg: Springer Verlag, 1986:274-81.

21 Delisle MB, Carpenter S. Neurofibrillary axonal swellings and amyotrohic lateral sclerosis. J Neurol Sci 1984;63:241-50.
22 Hirano A. Pathology of amyotrophic lateral sclerosis. In: Gajdusek DC, Gibbs CJ, Alpers M, eds. Slow, Latent and Temperate Virus Infections. Washington: National Institute of Health, 1965:23.

23 Johnson PC. Anterior horn cell eosinophilic cytoplasmic inclusion bodies in sporadic motor neuron disease of adults. J Neuropathol Exp Neurol 1976;35:368.

24 Delisle MB, Gorce P, Hirsch E, Hauw JJ, Rascol A, Bouissou H. Motor neuron disease, parkinsonism and dementia. Acta Neuropathol 1987;75:104-8.

25 Mitsuyama Y, Fukunaga H, Yamashita M. Alzheimer's disease with widespread presence of Lewy bodies. Folia Psychiatr Neurol Jpn 1984;38:81-8.

26 Minagawa M, Maeshiro N, Taguchi K, Shioda A. An autopsy case showing dementia and Shy-Drager syndrome with Lewy bodies and spheroids in substantia nigra and senile plaques in cerebral cortex. Neuropathology 1980;1:28-9.

27 Kosaka K. Lewy bodies in cerebral cortex. Report of three cases. Acta Neuropathol 1978;42:127-34.

28 Kuroda S, Hasokawa K, Iguchi K, Tateishi J. An autopsy case of presenile dementia with numerous Lewy bodies in the cerebral cortex. Clin Neurol 1978;18:346-50.

29 Yagishita S, Itoh Y, Amano N, Nakano T. Atypical senile dementia with widespread Lewy type inclusion in the cerebral cortex. Acta Neuropathol 1980;49:187-91.

30 Ikeda K, Hori A, Bode G. Progressive dementia with "diffuse Lewy-type inclusions" in cerebral cortex: a case report. Archiv fur Psychiatrie und Nervenkrankheiten 1980;228:243-8.

31 Ikeda K, Yoshimura T, Kato H. A case of idiopathic parkinsonism with many Lewy bodies in the cerebral cortex. Brain Nerve 1975;27:733-42.

32 Ogasawara N, Takamatsu K, Monma Y, Itoh T. Presenile Demenz mit senilen Veränderungen, argentophilen Kugeln und Levy Körperchen. J Neuropathol Exp Neurol 1978;37:667.

33 Monma Y, Takamatsu Y, Ogasawara H, Itoh T. Atypical presenile dementia with numerous Lewy bodies. Adv Neurol Sci 1979;23:598-9.

34 Kayano T, Funada N, Okeda R, Kojima T, Miki M, Iwama H. An autopsy case of Parkinson's disease with dementia and a wide distribution of Lewy-like bodies in cerebral cortex. Neuropathology 1980;1:27-8.

35 Sima AAF, Clark AW, Sternberger NA, Sternberger LA. Lewy body dementia without Alzheimer changes. Can J Neurol Sci 1986;13:490-7.

36 Clark AW, White CL, Manz HJ, et al. Primary degenerative dementia without Alzheimer pathology. Can J Neurol Sci 1986;13:462-70.

37 Dickson DW, Davies P, Mayeux R, Crystal H, Horoupian DS, Thompson A, Goldman JE. Diffuse Lewy body disease. Neuropathological and biochemical studies of six patients. Acta Neuropathol 1987;75:8-15.

38 Forno LS. Concentric hyalin intraneuronal inclusions of Lewy type in the brains of elderly persons (50 incidental cases). Relationship to Parkinsonism. J Am Geriatr Soc 1969;17: 557-75.

39 Jellinger K, Grisold W. Cerebral atrophy in Parkinson syndrome. Exp Brain Res 1982;suppl 5:26-35.

40 Gibb WRG, Lees AJ. Dementia in Parkinson's disease. Lancet 1987;i:861.

41 Pearce J. The extrapyramidal disorder of Alzheimer's disease. Eur Neurol 1974;12:94-103.

42 Drachman DA, Stahl S. Extrapyramidal dementia and levodopa. Lancet 1975;i:809.

43 Sulkava R. Alzheimer's disease and senile dementia of Alzheimer type. A comparative study. Acta Neurol Scand 1982;65:636-50.

44 Brown RG, Marsden CD. How common is dementia in Parkinson's disease? Lancet 1984;ii:1262-5.

45 Lees AJ. Cognitive deficits in Parkinson's disease. In: Traber J, Gispen WH, eds. Senile Dementia of the Alzheimer type: Early Diagnosis, Neuropathology and Animal Models. Berlin: Springer 
Verlag, 1985:60-71

46 Albert ML. Subcortical dementia. In: Katzman R, Terry RD, Bick RD, Bick KL, eds. Alzheimer's Disease: Senile Dementia and Related Disorders. Volume 7, Ageing. New York: Raven Press, 1978:173-80.

47 Mayeux R, Stern Y, Rosen J, Benson DF. Is "subcortical dementia" a recognizable clinical entity? Ann Neurol 1983;14:278-83.

48 Pillon B, Dubois B, Lhermitte F, Agid Y. Heterogeneity of cognitive impairment in progressive supranuclear palsy, Parkinson's disease, and Alzheimer's disease. Neurology 1986;36:1179-85.

49 Alvord EC, Forno LS, Kusske JA, Kauffman RJ, Rhodes JS Goetowski CR. The pathology of parkinsonism: A comparison of degenerations in cerebral cortex and brainstem. Adv Neurol 1974;5:175-93.

50 Hakim AM, Mathieson G. Dementia in Parkinson disease: a neuropathologic study. Neurology 1979;29:1209-14.

51 Boller F, Mitzutani T, Roessman U, Gambetti P. Parkinson disease, dementia and Alzheimer disease: clinicopathological correlations Ann Neurol 1980;7:329-35.

52 Tomlinson BE, Blessed G, Roth M. Observations on the brains of non-demented old people. J Neurol Sci 1968;7:331-56.

53 Heston LL. Genetic studies of dementia: with emphasis on Parkinson's disease and Alzheimer neuropathology. In: Mortimer JA, Schuman LM, eds. Epidemiology of Dementia.
New York: Oxford University Press, 1981:101-14.

54 Mann DMA, Yates PO. Pathological basis for neurotransmitter changes in Parkinson's disease. Neuropathol Appl Neurobiol 1983;9:3-19.

55 Ball MJ. The morphological basis of dementia in Parkinson's disease. Can J Neurol Sci 1984;11:180-4.

56 Whitehouse PJ, Hedreen JC, White CL, Price DL. Basal forebrain neurons in the dementia of Parkinson's disease. Ann Neurol 1983;13:243-8.

57 Gaspar P, Gray F. Dementia in idiopathic Parkinson's disease. Acta Neuropathol 1984;64:43-52.

58 Nakano I, Hirano A. Parkinson's disease: Neuron loss in the nucleus basalis without concomitant Alzheimer's disease. Ann Neurol 1984;15:415-8.

59 Perry EK, Curtis M, Dick DJ, et al. Cholinergic correlates of cognitive impairment in Parkinson's disease: comparisons with Alzheimer's disease. J Neurol Neurosurg Psychiatry 1985; 48:413-21.

60 Ditter SM, Mirra SS. Neuropathologic and clinical features of Parkinson's disease in Alzheimer's disease patients. Neurology 1987;37:754-60.

61 Leverenz J, Sumi M. Parkinson's disease in patients with Alzheimer's disease. Arch Neurol 1986;43:662-4.

62 Joachim JL, Morris J, Selkoe DJ. Autopsy neuropathology in 76 cases of clinically diagnosed Alzheimer's disease. Neurology 1986;36:suppl 1:226. 